\title{
Perencanaan dan Penataan Ruangan pada Bangunan Rumah Sakit Khusus Lansia (Geriatri) di Surakarta
}

\author{
Shafira Rizki Ananda \\ Program Studi Desain Interior, Fakultas Seni Rupa dan Desain, Universitas Sebelas Maret, \\ J1. Ir. Sutami No.36, Kentingan, Kec. Jebres, Kota Surakarta, Jawa Tengah 57126, Indonesia \\ Email korespondensi: shafirarizki14@gmail.com
}

Received 25 January 2021, Revised 22 April 2021, Accepted 11 May 2021

\begin{abstract}
The number of elderly people in Indonesia continues to increase every year, Surakarta is one of the cities with a high life expectancy, and it is targeted to be an elderly friendly city. One of the ways to support the government's target written above is by providing health facilities that are elder-friendly. The design process for the Elderly Hospital facility is carried out in several stages. These stages include conducting surveys and observations in pre-existing facilities, determining project locations, identifying user activities and space requirements, and compiling detailed design and programming concepts. The interior design of the Elderly Hospital uses a natural-homey concept, the goal is that elderly patients do not feel strange and actually feel like being at home. This concept is also supported by the application of a minimalist style, which is outlined in simple forms with the aim that cleanliness in the hospital is always maintained. In addition, complete facilities are also available and this hospital also implement a system that can reduce physical queues, thereby reducing the risk of fatigue in elderly patients. The design of the Elderly Hospital prioritizes the comfort of elderly patients in seeking treatment. One of the methods used to provide this comfort is the use of the natural homey concept, which is then applied in giving colour to the room, namely using variety of brown shades.
\end{abstract}

Keywords: hospital, geriatric, natural, homey

\begin{abstract}
Abstrak - Jumlah lansia di Indonesia terus meningkat setiap tahunnya. Surakarta merupakan salah satu kota dengan angka harapan hidup yang tinggi, serta ditargetkan menjadi kota yang ramah lansia. Salah satu cara untuk mendukung target pemerintah tersebut yaitu dengan menyediakan fasilitas kesehatan yang ramah lansia. Proses desain fasilitas Rumah Sakit Lansia dilakukan dengan beberapa tahapan. Tahapan-tahapan tersebut antara lain melakukan survey dan observasi di fasilitas yang telah ada sebelumnya, menentukan lokasi proyek, mengidentifikasi kegiatan pengguna serta kebutuhan ruang, serta menyusun konsep desain dan programming secara rinci. Desain interior Rumah Sakit Khusus Lansia ini menggunakan konsep natural homey, tujuannya adalah agar pasien lansia tidak merasa asing dan justru merasakan nuansa seperti berada di rumah. Konsep ini juga didukung dengan penerapan gaya minimalis, yang dituangkan dalam bentuk-bentuk sederhana dengan tujuan agar kebersihan di dalam rumah sakit selalu terjaga. Selain itu juga tersedia fasilitas lengkap dan menerapkan sistem yang dapat mengurangi antrean fisik, sehingga dapat mengurangi risiko kelelahan pada pasien lansia. Desain Rumah Sakit Khusus Lansia mengutamakan kenyamanan pasien lansia dalam berobat. Salah satu cara yang digunakan untuk memberikan kenyamanan tersebut adalah penggunaan konsep natural homey, yang kemudian diterapkan dalam pemberian warna pada ruangan, yaitu menggunakan nuansa cokelat. Kata kunci: Rumah Sakit, Geriatri, Natural, Homey
\end{abstract}

\section{PENDAHULUAN}

Jumlah lansia di Indonesia terus meningkat setiap tahunnya, dan diprediksi pada tahun 2025 jumlahnya akan mencapai 33,7 juta jiwa atau $11,8 \%$ dari total penduduk Indonesia. Populasi lanjut usia di Kota Surakarta juga termasuk tinggi. Menurut data sensus tahun 2010, jumlah masyarakat yang berusia di atas 60 tahun di Surakarta mencapai 9\%. Persentase tersebut lebih tinggi daripada rata-rata nasional yang hanya sebesar $7 \%$. Hal ini dapat dipengaruhi oleh angka harapan hidup yang lebih tinggi di kota ini, yaitu mencapai rata-rata 72 tahun. Karena itu, pemerintah Kota Surakarta mentargetkan untuk menjadikan Kota Surakarta sebagai kota ramah lansia (Pusat Data dan Informasi Kemetrian Kesehatan RI, 2013).

Berdasarkan standar yang ditetapkan WHO untuk mencapai indikator kota ramah lansia, salah 
satu indikatornya adalah dukungan masyarakat dan kesehatan. Saat ini Kota Surakarta sudah memberikan pelayanan kesehatan lansia dengan baik, seperti tersedianya layanan puskesmas khusus lansia, petugas kesehatan yang rutin berkunjung ke kampung, hingga administrasi yang tidak menyulitkan. Namun fasilitas kesehatan lansia yang tersedia masih memiliki kendala antara lain tidak memiliki system pemeriksaan yang lengkap, sistem kurang efektif, dan sering terkendala di antrean yang membuat lelah (Suriastini, 2013).

Selain itu, lingkungan yang tercipta di posyandu dan rumah sakit yang telah tersedia tidak dirancang secara khusus menjadi lingkungan yang ramah bagi pasien lansia. Lingkungan yang dimaksud dapat dilihat dari segi desain maupun teknis ruangannya hingga pelayanan tim medis terhadap pasien lansia, karena pasien lansia tidak hanya membutuhkan penanganan medis seperti pasien umum, tapi membutuhkan pelayanan kesehatan secara holistik. Maka penting untuk memperhatikan bagaimana standar RS Lansia yang baik (Anggawirya, 2019).

Menurut Buku Code Plus: Physical Design Components for An Elder Friendly Hospital (Parke dan Kathleen, 2007), Standar RS Lansia didasarkan pada kondisi fisiologis lansia, dimana kondisi fisiologis lansia yang berubah akibat penuaan mempengaruhi sejumlah elemen desain RS Lansia. Hal ini karena standar RS Lansia dapat mempengaruhi fungsi independen dan keamanan lansia yang dirawat di rumah sakit. Standar RS Lansia meliputi desain fisik yang harus mempertimbangkan aspek keamanan, kenyamanan, mobilitas, isyarat memori, isyarat visual dan persepsi pendengaran (Gallagher, 2018).

Terdapat beberapa aspek yang perlu disesuaikan untuk mencapai standar RS lansia, seperti pencahayaan, warna, lantai, dinding, pintu, jendela, lorong, papan petunjuk jalan, tangga, parker, elevator, kamar mandi, furniture. Beberapa contoh standar RS Lansia yaitu terkait pencahayaan dimana jika memungkinkan, gunakan pencahayaan alami, hindari lampu yang menyilaukan pandangan, gunakan warna cat yang kontras antara dinding dan lantai untuk dapat dibedakan oleh lansia, hindari desain dinding dan lantai yang licin dan menyilaukan, sediakan pegangan di beberapa area seperti area lorong yang tidak licin dan kontras warnanya dengan dinding, gunakan pintu otomatis atau pintu yang mudah dibuka, dan sediakan papan nama petunjuk dengan penempatan yang tepat (Parke dan Kathleen, 2007).

Berdasarkan dari permasalahan tersebut peneliti ingin menyelesaikan masalah melalui ide untuk menghasilkan desain interior rumah sakit khusus lansia dengan fasilitas lengkap dan interior ramah lansia. Selain itu peneliti ingin menghasilkan desain interior dengan konsep natural dan homey. Sehingga berdasarkan permasalahan tersebut maka penelitian ini bertujuan untuk menghasilkan desain interior rumah sakit khusus lansia dengan fasilitas lengkap dan interior ramah lansia dengan konsep natural dan homey. Harapannya penelitian ini dapat bermanfaat bagi pemerintah dan masyarakat agar dapat memberikan alternatif rancangan interior untuk rumah sakit khusus lansia dan memberikan alternatif solusi bagi pasien lansia agar mendapatkan kenyamanan ketika berobat. Selain itu penelitian ini diharapkan bermanfaat bagi desainer agar dapat memperoleh pengetahuan wawasan tentang perancangan interior untuk fasilitas rumah sakit khusus lansia serta dapat mengembangkan kreativitas desainer terhadap perancangan ruang, furniture, dan landscape dengan mengedepankan aspek fungsional maupun estetika.

\section{METODOLOGI DESAIN Lokasi Studi}

Lokasi studi dibutuhkan untuk melakukan pengumpulan data yang bertujuan untuk mengetahui kebutuhan ruang dan pelayanan yang tersedia di RS. Proses pengumpulan data dilakukan dengan meninjau langsung objek serupa (survey) untuk mendapatkan data yang berhubungan langsung dengan kebutuhan interior pada fasilitas kesehatan khusus lansia. Peninjauan objek serupa dilakukan pada dua lokasi, yaitu Klinik Geriatri Wijayakusuma Bogor dan Bogor Senior Hospital dengan cara wawancara dengan pihak terkait untuk mengetahui kebutuhan pada fasilitas kesehatan khusus lansia baik dari segi teknis bangunan maupun pelayanan. Observasi lokasi juga dilakukan sebagai dasar pertimbangan dalam pengelompokkan kebutuhan dan penentuan konsep.

Hasil dari pengumpulan data yaitu diperoleh kedua RS menyediakan ruangan antara lain IGD, ICU, instalasi farmasi, poliklinik spesialis, rehabilitasi medik, kamar operasi, ruang rawat inap, dan laboratorium. Selain itu diperoleh gambaran kondisi masing-masing ruangan serta pelayanan bagi lansia di kedua RS tersebut. Kesimpulan dari pengumpulan data adalah bahwa kondisi ruangan di RS tersebut menunjukkan pemilihan warna cat yang terlalu terang dan terkesan dingin, pencahayaan terlalu terang, serta permukaan lantai yang memantulkan cahaya, dimana kondisi tersebut kurang baik untuk penglihatan lansia. Selain itu kondisi koridor yang didesain terkesan membingungkan, hal ini dapat menyulitkan lansia saat berjalan di koridor. Kemudian kursi tunggu yang terdapat di RS juga memiliki permukaan keras, dimana kondisi kursi tersebut tidak cocok untuk lansia. Berdasarkan dari hasil pengumpulan data, maka kesimpulan tersebut dijadikan dasar titik tolak perancangan oleh peneliti.

\section{Analisa Data}

Analisa data diperoleh dari hasil survey, wawancara, observasi objek serupa, serta dari hasil 
studi literatur. Tahapan analisa data yaitu setelah diperoleh data primer kemudian dianalisa untuk disusun konsep skematik yang terdiri dari: Zoning, Grouping, besaran ruang, organisasi ruang, alur sirkulasi, dan pola hubungan antar ruang. Berdasarkan data hasil observasi yang diperoleh serta berdasarkan analisis, persyaratan teknis klinik dan rumah sakit khusus lansia yang tersedia telah terpenuhi, namun belum menerapkan perancangan interior yang ramah bagi pasien lansia.

Hasil dari observasi menunjukkan bahwa kondisi ruangan di RS memiliki warna cat yang terlalu terang dan terkesan dingin, pencahayaan terlalu terang, serta permukaan lantai yang memantulkan cahaya, dimana kondisi tersebut kurang baik untuk penglihatan lansia. Selain itu kondisi koridor yang didesain terkesan membingungkan, hal ini dapat menyulitkan lansia saat berjalan di koridor. Kemudian kursi tunggu yang terdapat di RS juga memiliki permukaan keras, dimana kondisi kursi tersebut tidak cocok untuk lansia.

Kondisi RS tersebut dinilai tidak sesuai dengan literature, di mana Parke dan Kathleen (2007) menjelaskan bahwa terdapat beberapa aspek yang perlu disesuaikan untuk mencapai standar RS lansia, seperti pencahayaan, warna cat, lantai, dinding, pintu, jendela, lorong, papan petunjuk jalan, tangga, elevator, kamar mandi, dan furniture.

Standar warna cat di RS Lansia memiliki rona warna panas, dengan pencahayaan alami dan tidak terlalu terang, permukaan lantai yang cenderung matte dan tidak licin sehingga tidak menimbulkan kilau cahaya. Untuk area koridor sediakan pegangan yang tidak licin dan kontras warnanya dengan dinding dan sediakan papan nama petunjuk dengan penempatan yang tepat. Untuk kursi digunakan kursi dengan permukaan yang empuk dan ergonomis agar tidak menyulitkan pasien lansia ketika duduk.

\section{HASIL PENELITIAN DAN ANALISIS Konsep Perancangan}

Perancangan rumah sakit ini menerapkan konsep pelayanan all in one, dimana nantinya seluruh kebutuhan pasien lansia tersedia dalam satu bangunan ini. Mulai dari konsultasi dokter, penanganan medis seperti terapi fisik maupun psikis, hingga pembelian obat serta alat kesehatan.

Hasil analisis konsep perancangan ini menunjukkan bahwa konsep all in one telah sesuai dengan konsep RS yang ramah bagi lansia. Dimana konsep all in one tidak hanya menyediakan segala kebutuhan pasien di satu atap rumah sakit, namun juga menyediakan pelayanan yang nyaman untuk para pasien lansia baik dari segi pelayanan maupun fasilitas, terutama pada lingkungan dan atmosfer yang diciptakan di rumah sakit ini.

Pemilihan konsep all in one dinilai telah sesuai dengan tujuan penelitian yaitu menciptakan RS yang ramah bagi lansia, memudahkan serta mengurangi ketidaknyamanan yang dirasakan pasien lansia.

\section{Tema Perancangan}

Tema yang akan diterapkan pada desain rumah sakit ini adalah tema minimalis, di mana menurut Peraturan Menteri Kesehatan Republik Indonesia no. 24 tahun 2016 tentang Persyaratan Teknis Bangunan dan Prasarana Rumah Sakit, ketentuan desain komponen bangunan rumah sakit harus dapat meminimalisir penyebaran infeksi.

Hasil analisis tema perancangan ini menunjukkan bahwa tema minimalis telah sesuai dengan ketentuan yang ditetapkan pemerintah. Selain itu tema minimalis juga dapat dikombinasikan dengan konsep homey, di mana konsep suasana homey menciptakan kesan nyaman bagi lansia. Pemilihan tema minimalis didasarkan pada pengaplikasian bentuk-bentuk elemen interior yang sederhana, sehingga memberikan kemudahan dalam pemeliharaan kebersihan, serta dapat meminimalisir penyebaran infeksi di area rumah sakit.

\section{Sirkulasi dan Organisasi Ruang}

Sistem sirkulasi yang digunakan pada proyek ini adalah komposit atau gabungan, karena dalam bangunan terdapat beberapa sirkulasi seperti grid dan linier. Sistem sirkulasi komposit atau gabungan merupakan sebuah bangunan yang biasanya menggunakan kombinasi pola-pola sebelumnya. Sistem sirkulasi komposit digunakan untuk menghindari terciptanya pola yang membingungkan. Tatanan hierarki dalam sirkulasi juga ditetapkan (Ching, 2000).

Berdasarkan analisis konsep RS ramah lansia menunjukkan bahwa sistem sirkulasi komposit atau gabungan cocok diterapkan pada RS lansia, hal ini karena sirkulasi tersebut berguna untuk menciptakan pola yang tersistem agar tidak membingungkan lansia.

Sedangkan sistem organisasi dalam perancangan proyek ini menggunakan sistem organisasi cluster, yaitu dengan mengelompokkan ruang berdasarkan keterkaitan fungsi dan bentuk visualnya. Sistem organisasi cluster ini menghubungkan satu ruangan dengan ruangan lain yang memiliki keterkaitan fungsi (Ching, 2000).

Hasil analisis menunjukkan bahwa konsep sistem organisasi cluster sesuai dengan konsep RS ramah lansia, hal ini karena system organisasi tersebut bertujuan untuk membuat cluster agar pasien lansia mudah mengakses ruangannya. Konsep cluster ini sangat praktis dan fungsional untuk diterapkan.

Pemilihan Sistem sirkulasi komposit atau gabungan dan sistem organisasi cluster dinilai telah sesuai dengan tujuan penelitian yaitu menciptakan RS yang ramah bagi Lansia dan memudahkan akses serta mobilitas lansia. 


\section{Pencahayaan dan Penghawaan}

Untuk mendapatkan pencahayaan alami yang maksimal dari matahari, dapat dilakukan penempatan jendela berukuran besar di ruangan tertentu, menyesuaikan pada kebutuhannya. Untuk ruangan yang membutuhkan tingkat fokus yang tinggi seperti ruang radiologi dan laboratorium dapat menggunakan lampu LED sebagai pencahayaan buatan yang hemat energi. Sedangkan untuk penghawaan, menggunakan $\mathrm{AC}$ merupakan pilihan terbaik untuk proyek rumah sakit karena dapat meminimalisir masuknya debu dari bukaan seperti jendela.

Hasil analisis pencahayaan dan penghawaan ini menunjukkan bahwa pencahayaan dan penghawaan telah sesuai dengan konsep RS yang ramah bagi lansia. Di mana Standar RS Lansia menurut Parke dan Kathleen (2007) adalah terkait pencahayaan dimana jika memungkinkan, gunakan pencahayaan alami. Selain itu dapat digunakan jendela terbuka dengan pembatas dan layar pada jendela untuk keamanan, hal ini bertujuan untuk membiarkan sinar matahari masuk ke seluruh ruangan RS. Kemudian untuk di beberapa area dapat digunakan AC untuk mengurangi masuknya debu ke dalam ruangan pasien lansia.

Pemilihan pencahayaan dan penghawaan tersebut dinilai telah sesuai dengan tujuan penelitian yaitu menciptakan RS yang ramah bagi Lansia dan mengurangi ketidaknyamanan yang dirasakan pasien lansia. Selain itu pencahayaan dan penghawaan tersebut dapat mengurangi terjadinya kontaminasi bakteri dari luar jendela serta meningkatkan keamanan ruangan lansia.

\section{Zoning dan Grouping}

Zoning berguna untuk menentukan tingkat privasi. Tingkat privasi meliputi publik, semi-publik, privat. Warna kuning menunjukkan tingkat privasi publik, dapat diakses umum. Warna ungu menunjukkan tingkat privasi semi-publik, dapat diakses oleh pihak tertentu misalnya pasien dan keluarga pasien yang terdaftar dan tenaga medis yang berwenang. Warna merah muda menunjukkan tingkat zona privat, dimana tingkat privasi ini lebih tinggi dari semi publik (Ching, 2000).

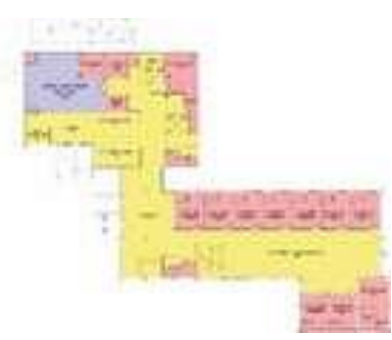

Gambar 1. Zoning lantai 1

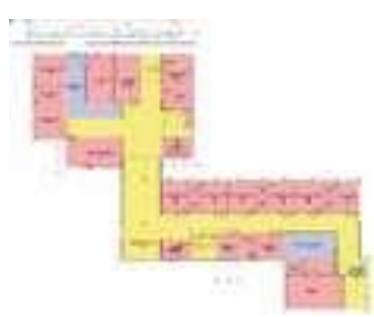

Gambar 2. Zoning lantai 2

Berdasarkan Gambar 1. Mayoritas zona berwarna kuning sedangkan pada Gambar 2. Mayoritas zona berwarna merah muda. Hal ini menunjukkan bahwa tingkat privasi di tiap area berbeda-beda. Tingkat privasi dalam konsep zoning sesuai dengan konsep ramah lansia, dimana lansia tetap membutuhkan ruang privasi dan hal ini terkait dengan kenyamanan lansia.

Grouping berguna untuk menentukan ruang berdasarkan fungsi dan hubungan antar ruangan. Ruangan dengan fungsi yang sama seperti ruang dokter dan ruang rawat inap diletakkan dalam satu area (Ching, 2000). Hal ini sesuai dengan Gambar 3. dan Gambar 4. Ruangan yang memiliki hubungan dekat juga diletakkan berdekatan misalnya ruang IGD dengan lobby dan farmasi. Selain itu IGD juga ditempatkan dekat lift sehingga jika terjadi tindakan darurat dapat dengan segera dibawa ke ruang operasi di lantai 2. Konsep grouping sesuai dengan konsep ramah lansia, dimana ruang yang dikelompokkan memudahkan pasien lansia dan dokter maupun perawat dalam menangani pasien lansia, sekaligus memudahkan akses mereka.

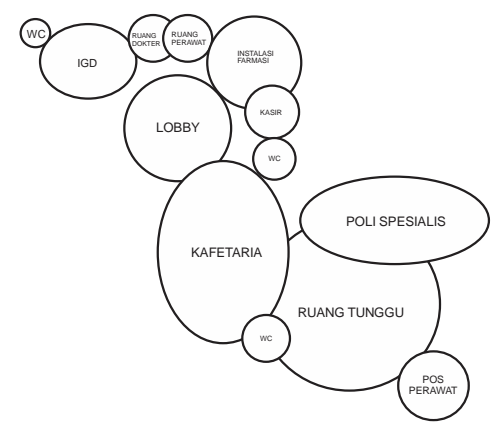

Gambar 3. Grouping lantai 1

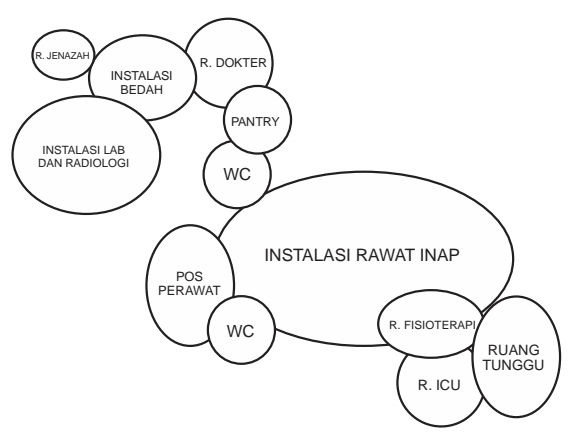

Gambar 4. Grouping lantai 2 


\section{WUJUD KARYA}

\section{Instalasi Gawat Darurat}

Hasil layout instalasi gawat darurat ditunjukkan pada Gambar 5. Berdasarkan Gambar 5. menunjukkan bahwa instalasi gawat darurat memiliki tinggi lantai $+0.50 \mathrm{~m}$. Kondisi medis yang dialami oleh pasien lansia cenderung unik dan berbeda dengan pasien umum. Pasien lansia lebih sensitif terhadap cahaya, suhu, dan bunyi. Instalasi Gawat Darurat yang tersedia di rumah sakit umum biasanya cenderung ramai, dipenuhi oleh pasien dari berbagai kalangan usia. Hal ini dapat membuat pasien lansia tidak nyaman secara fisik dan mental. Untuk itu, diberlakukan pembatasan pasien sebanyak maksimal 4 orang pasien secara bersamaan sehingga pasien lansia tetap merasa nyaman.

Tampak perspektif IGD ditunjukkan pada Gambar 6. Dari Gambar 6. Menunjukkan bahwa IGD memiliki cat warna bernuansa cokelat warm tone.

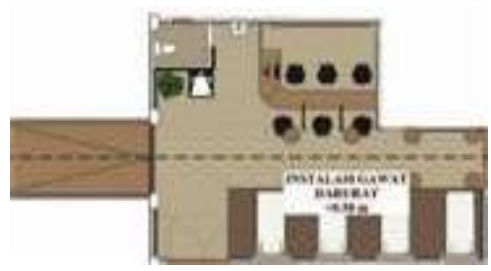

Gambar 5. Layout Instalasi Gawat Darurat

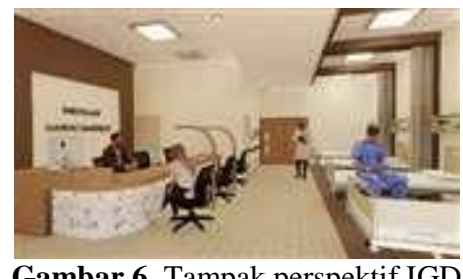

Gambar 6. Tampak perspektif IGD

\section{Lobby / Resepsionis}

Hasil layout lobby ditunjukkan pada Gambar 7. Berdasarkan Gambar 7, menunjukkan bahwa layout lobby memiliki 4 bagian yaitu area screening, informasi, registrasi, dan ruang tunggu, serta memiliki tinggi lantai $+0.50 \mathrm{~m}$.

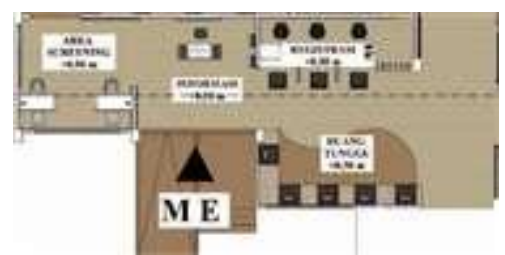

Gambar 7. Tampak layout lobby

Pada Gambar 8 dan Gambar 9 menunjukkan tampak perspektif lobby. Seperti desain bangunan secara keseluruhan, lobby menggunakan konsep homey yang ditandai dengan rona warna bernuansa cokelat pada setiap sisinya. Beberapa warna cokelat dikombinasikan dengan tekstur kayu serta tekstur alami lain seperti corak marmer dan batu alam pada backdrop untuk mempertegas kesan natural. Lobby juga didesain untuk menghindari jumlah pasien terlalu ramai, sehingga kursi tunggu yang tersedia sangat dibatasi. Hal ini juga merupakan salah satu solusi yang dapat diterapkan saat kondisi pandemi seperti sekarang ini. Peletakan kursi dengan jarak minimal 1,5 meter dan pemasangan flexiglass pada meja resepsionis dapat mendukung pelaksanaan pembatasan sosial di rumah sakit.

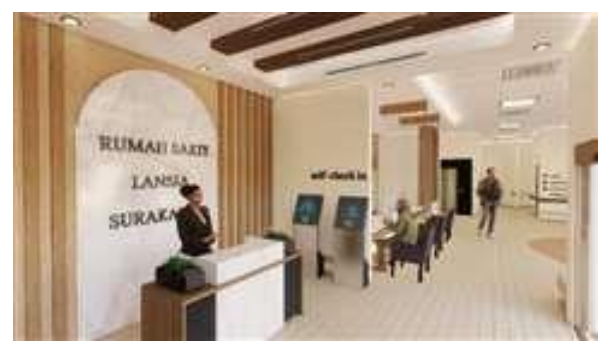

Gambar 8. Tampak 1 perspektif lobby

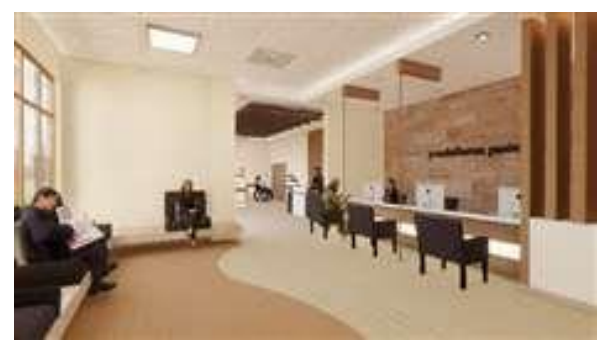

Gambar 9. Tampak 2 perspektif lobby

\section{Instalasi Farmasi}

Hasil instalasi farmasi ditunjukkan pada Gambar 10. Berdasarkan Gambar 10, menunjukkan bahwa instalasi farmasi memiliki 3 bagian yaitu ruang racik obat, kasir, dan instalasi farmasi, serta memiliki tinggi lantai $+0.50 \mathrm{~m}$.

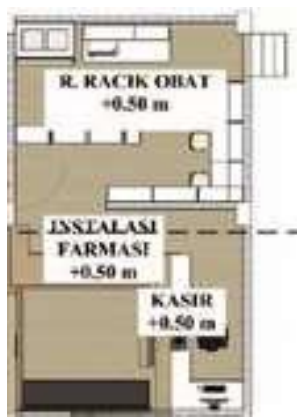

Gambar 10. Tampak layout Instalasi Farmasi

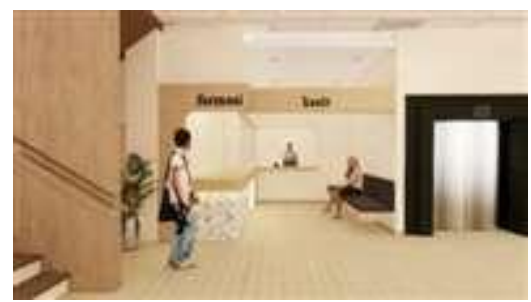

Gambar 11. Tampak perspektif Instalasi Farmasi

Tampak perspektif instalasi farmasi ditunjukkan pada Gambar 11. Pada Gambar 11 Instalasi Farmasi terdiri dari ruang racik obat yang memiliki akses langsung ke luar untuk keperluan loading. Selain itu juga terhubung dengan kasir dan 
meja yang langsung mengarah ke area lobby. Terdapat kursi panjang di area instalasi farmasi yang diperuntukkan bagi pasien atau pendamping pasien ketika harus mengantre. Meja farmasi menggunakan HPL dengan corak granit di bagian depan, serta dipasangkan lampu LED strip di sekelilingnya untuk menampilkan kesan hangat dan tidak monoton.

\section{Kafetaria}

Tampak layout kafertaria ditunjukkan pada Gambar 12. Berdasarkan Gambar 12, menunjukkan bahwa layout kafetaria memiliki 1 bagian yaitu kafetaria dengan tinggi lantai $+0.50 \mathrm{~m}$.

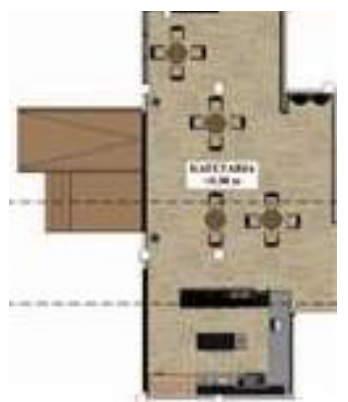

Gambar 12. Tampak layout Kafetaria

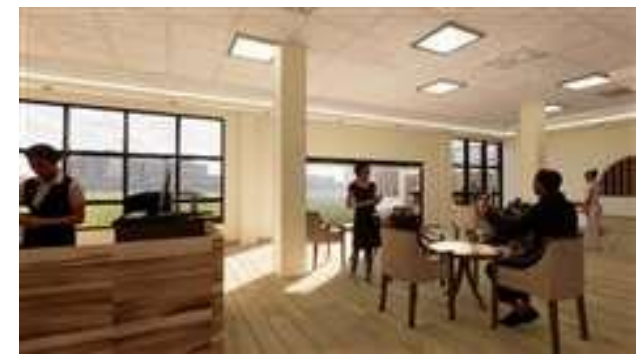

Gambar 13. Tampak 1 perspektif Kafetaria

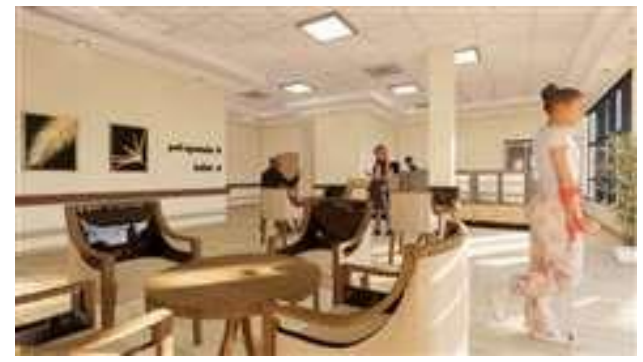

Gambar 14. Tampak 2 perspektif Kafetaria

Tampak perspektif kafetaria ditunjukkan pada Gambar 13 dan Gambar 14. Berdasarkan pada Gambar 13 dan Gambar 14 menunjukkan bahwa kafetaria memiliki desain simple, homey, dan bernuansa coklat. Kafetaria disediakan pagi pasien maupun pendamping pasien dengan pengaturan meja dan kursi yang tidak terlalu banyak. Hal ini juga disesuaikan dengan luas ruangan yang tersedia serta pengaplikasian pembatasan sosial. Dengan adanya kafetaria di bagian tengah bangunan, dapat memudahkan pengunjung dari kedua sudut bangunan untuk mengaksesnya. Pintu yang tersedia di dekat kafetaria ini digunakan sebagai pintu khusus keluar selama penerapan pembatasan sosial, sehingga terjadi sirkulasi satu arah.

\section{Ruang Tunggu Spesialis}

Tampak layout ruang tunggu spesialis ditunjukkan pada Gambar 15. Berdasarkan Gambar 15, menunjukkan bahwa layout ruang tunggu spesialis memiliki 1 bagian yaitu ruang tunggu dengan tinggi lantai $+0.50 \mathrm{~m}$.

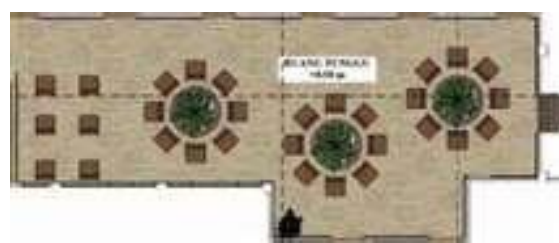

Gambar 15. Tampak layout Ruang Tunggu Spesialis

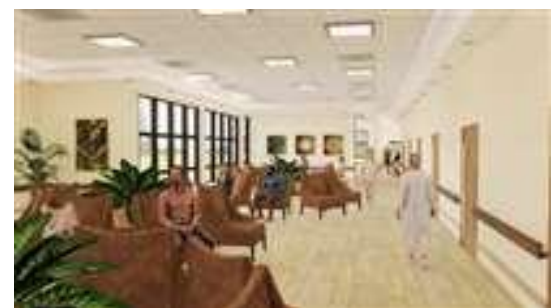

Gambar 16. Tampak perspektif Ruang Tunggu Spesialis

Tampak perspektif ruang tunggu spesialis ditunjukkan pada Gambar 16. Pada ruang tunggu spesialis, kursi tunggu diposisikan secara melingkar mengelilingi dekorasi tanaman berukuran besar. Penempatan kursi tunggu secara melingkar bertujuan untuk membuat ruangan terlihat lebih dinamis, serta juga mendukung penerapan pembatasan sosial, karena pasien lansia memiliki kondisi yang cukup rentan terpapar virus. Sedangkan tanaman besar merupakan respon dari penggunaan konsep natural pada bangunan.

\section{Ruang Dokter Spesialis}

Hasil layout ruang dokter spesialis ditunjukkan pada Gambar 17. Berdasarkan Gambar 17, menunjukkan bahwa layout ruang dokter spesialis memiliki 1 bagian yaitu ruang dokter spesialis dengan tinggi lantai $+0.50 \mathrm{~m}$.

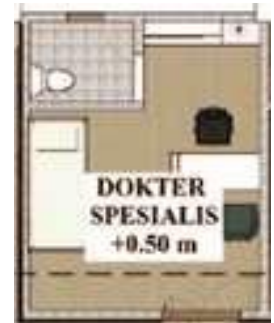

Gambar 17. Tampak layout Ruang Dokter Spesialis

Bentuk furnitur pada ruang dokter spesialis didesain secara minimalis dan sederhana, dengan menambahkan sentuhan warna hijau pada kursi pasien untuk mempertahankan kesan natural (earth tone). Terdapat kamar mandi yang digunakan khusus untuk 
dokter, dan kabinet kecil yang terletak di belakang meja dokter untuk menyimpan arsip maupun barang pribadi dokter.

\section{Kamar Rawat Inap}

Hasil layout kamar rawat inap ditunjukkan pada Gambar 18. Berdasarkan Gambar 18. menunjukkan bahwa layout kamar rawat inap memiliki 1 bagian yaitu ruang rawat inap dengan tinggi lantai $+0.50 \mathrm{~m}$.

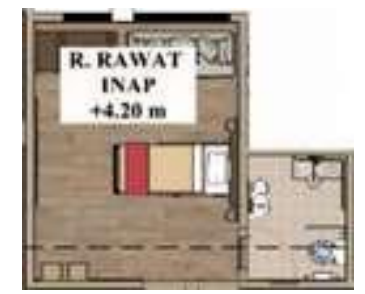

Gambar 18. Tampak layout Ruang Rawat Inap

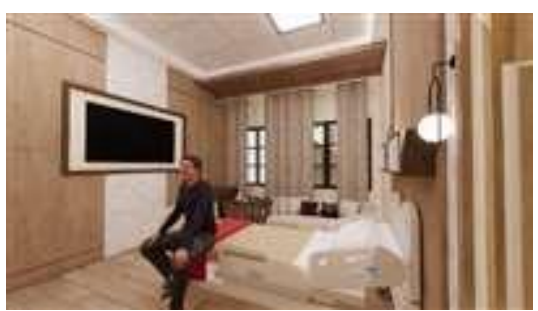

Gambar 19. Tampak perspektif Ruang Rawat Inap

\section{KESIMPULAN}

Rumah Sakit Khusus Lansia tidak hanya menyediakan fasilitas kesehatan seperti rumah sakit pada umumnya, namun juga mempertimbangkan aspek desain sebagai salah satu aspek yang menunjang rasa nyaman bagi pasien lansia. Nuansa seperti berada di rumah merupakan alternatif yang cocok diaplikasikan pada interior rumah sakit khusus lansia, tujuannya supaya pasien lansia dapat merasakan suasana yang hangat dan tidak asing. Konsep ini kemudian disebut dengan konsep homey, yang dalam pengembangannya dipadukan dengan konsep natural serta gaya interior minimalis. Gabungan konsep ini diterapkan pada seluruh elemen interior bangunan Rumah Sakit mulai dari lantai, dinding, ceiling, hingga elemen-elemen dekoratif.

\section{DAFTAR PUSTAKA}

Amrillah, Septia Rizkia dan Nanik Rachmaniyah. 2014. Desain Interior Clubhouse dengan Nuansa Modern Natural. Jurnal Seni dan Sains POMITS, Vol. 3(1)

Anggawirya, A. A. B. Bayu, dkk. 2019. Klinik Utama Geriatri di Denpasar, Bali (Penerapan Tema Healthy Building pada Perancangan Bangunan). $e$ Jurnal Arsitektur Universitas Udayana. Vol. 7(1), 1-6.

Ching, Francis D.K. 1996. Interior Design Illustrated. Terjemahan Paul Hanoto Adjie. Ilustrasi Desain Interior. Jakarta: Erlangga.

Ching, Francis D.K. 2000. Architecture: Form, Space, and Order. John Wiley and Sons, Inc. Terjemahan
Hanggan Situmorang. 2008. Arsitektur: Bentuk, Ruang dan Tatanan. Edisi ke-2. Jakarta: Erlangga.

Gallagher, K. 2018. Checklist for Designing a Geriatric Treatment Room in the Emergency Department. Pennsylvania: Facility Guidelines Institute

Parke, B., dan Kathleen, F. 2007. Codeplus Physical Design Components For An Elder Friendly Hospital. Canada: Fraser Health.

Pusat Data dan Informasi Kemetrian Kesehatan RI. 2013. Gambaran Kesehatan Lanjut Usia di Indonesia. Buletin Jendela Data dan Informasi Kesehatan. Vol. 1:1-18.

Puspita, Riski dan Prasetyo Wahyudie. 2017. Penerapan Konsep Modern Natural dengan Sentuhan Etnik Tengger Pada Desain Interior Hotel Bromo Permai 1. Jurnal Sains dan Seni ITS, Vol. 6(1)

Republik Indonesia. 2016. Peraturan Menteri Kesehatan Republik Indonesia Nomor 24 Tahun 2016 tentang Persyaratan Teknis Bangunan dan Prasarana Rumah Sakit. Lembaran Negara Republik Indonesia Tahun 2016 Nomor 1197. Jakarta.

Republik Indonesia. 2020. Peraturan Menteri Kesehatan Republik Indonesia Nomor 3 Tahun 2020 tentang Klasifikasi dan Perizinan Rumah Sakit. Lembaran Negara Republik Indonesia Tahun 2016 Nomor 1197. Jakarta.

Suriastini, Ni Wayan, dkk. 2013. Satu Langkah Menuju Impian Lanjut Usia. Kota Ramah Lanjut Usia, Kota Surakarta. Yogyakarta: Surveymeter. 